Relations industrielles

Industrial Relations

\title{
The History of Management Thought, par Claude George, Jr., Second Edition, Englewood Cliffs, N.J., Prentice-Hall, Inc., 223 \\ pp.
}

\section{Gérard Dion}

\section{Volume 28, numéro 1, 1973}

URI : https://id.erudit.org/iderudit/028384ar

DOI : https://doi.org/10.7202/028384ar

Aller au sommaire du numéro

\section{Éditeur(s)}

Département des relations industrielles de l'Université Laval

ISSN

0034-379X (imprimé)

1703-8138 (numérique)

Découvrir la revue

Citer ce compte rendu

Dion, G. (1973). Compte rendu de [The History of Management Thought, par Claude George, Jr., Second Edition, Englewood Cliffs, N.J., Prentice-Hall, Inc., 223 pp.] Relations industrielles / Industrial Relations, 28(1), 222-222.

https://doi.org/10.7202/028384ar

Tous droits réservés @ C Département des relations industrielles de l'Universite Laval, 1973
Ce document est protégé par la loi sur le droit d'auteur. L’utilisation des services d'Érudit (y compris la reproduction) est assujettie à sa politique d'utilisation que vous pouvez consulter en ligne.

https://apropos.erudit.org/fr/usagers/politique-dutilisation/ 
quence de faire naître des sentiments de frustration. Ceux-ci, nous enseignent la psychologie, se traduisent obligatoirement par l'un des trois comportements suivants : l'agressivité, la fuite ou la compensation; agressivité vis-à-vis de la direction, des cadres et de la mâ̂trise, fuite devant le travail, les responsabilités, et disparition de la conscience professionnelle ; compensation, par la recherche d'autres centres d'intérêt que le travail, le jeu ou l'alcool, par exemple, et instabilité du travailleur qui devient l'un de ces éternels insatisfaits s'imaginant qu'un changement d'emploi leur apportera une amélioration».

On se rend donc compte que l'auteur, sans négliger le côté strictement technique de la gestion du personnel, attache une importance de bon aloi à leur aspect humain.

L'ouvrage fournit, à la fin de chaque chapitre une bibliographie intéressante qui permet de voir en même temps qu'il s'agit d'une oeuvre assez dense tout de même que l'auteur a voulu écrire dans une langue décantée de cette sorte de vocabulaire technique qui rend parfois ces sortes de travaux quasi inaccessibles aux profanes. On pourrait ajouter, comme il s'agit d'un ouvrage publié en France et qui reste assez schématique, qu'on $\mathrm{y}$ relève un nombre considérable de termes bien français dont la connaissance pourrait être fort utile à ceux qui chez nous, devant souvent recourir à des manuels rédigés en langue anglaise, sont souvent dans l'obligation d'improviser la traduction à pied levé.

\section{André ROY}

\section{The History of Management Thought,} par Claude George, Jr., Second Edition, Englewood Cliffs, N.J., PrenticeHall, Inc. 1972, 223 pp.

Exposer en deux cents pages l'histoire du management depuis les civilisations les plus reculées en passant par le moyen-âge, la révolution industrielle et les développements des méthodes scientifiques jusqu'à nos jours est un défi extraordinaire.

L'auteur a su éviter les écueils d'une telle entreprise dont les non moindres étaient sûrement une simplification sommaire et le romanesque. Sans doute, dans un sujet aussi vaste, il a été amené à faire des choix. Mais il a retenu l'essentiel et le présente d'une façon synthétique claire, ordonnée et logique. Le tout est complété par une excellente bibliographie choisie.

Cet ouvrage peut être un instrument utile tant aux professeurs et aux. élèves qu'aux praticiens dans le domaine de la gestion.

\section{Gérard DION}

\section{Bargaining : Monopoly versus Union}

Power, by George de Menil, The Joint Center for Urban Studies of The Massachusetts Institute of Technology and Harvard University. The MIT Press, Cambridge, Massachusetts and London, England, 1971, 123 pp.

This book tackles the difficult subject of wage determination in the labor markets of highly unionized and concentrated industries where the standard models of competition, monopoly, and monopolistic competition do not apply. It attempts to bridge the gap between untested, abstract bargaining models and empirical studies that relate wages to 《bargaining variables 》 without the benefit of formal theory. To do this the study derives a wage equation from a bargaining model and then tests this equation on data for manufacturing industries in the United States, drawing conclusions that have important: implications for income distribution and for the analysis of union - non-union wage differentials.

The study presents a survey of some bargaining theories, selects one that the author finds most applicable -- Nash' theory of bargaining which is a branch of the theory of games of Von Neumann and Morgenstern - and from it constructs a model of the firm under bilateral monopoly. Assumptions are made concerning the product demand curve, production function, capital supply, supply of union members and the utility functions of the employer and the union. These assumptions plus two hypotheses from Nash's theory determine the wage rate, employment, capital stock, output, price and profits under bilateral monopoly.

The bargaining wage equation derived from the Nash bilateral monopoly mo- 